\title{
Reform of housing-and-communal services at the federal, regional and municipal levels of management, as the basis of improvement of communication of the state and its population
}

\author{
Oksana Skrypnik ${ }^{1, *}$ \\ ${ }^{1}$ Moscow State University of Civil Engineering, Yaroslavskoe shosse, 26, Moscow, 129337, Russia
}

\begin{abstract}
The matters of housing and communal services institutional transformations, the role of the state, as guarantor of constitutional rights and freedoms to each citizen on worthy housing, by means of realization of state mechanisms at each level of management are considered in the article. The historical development of the housing market can be considered through the system of institutional changes with respect to the development of the economy and enhancement of the infrastructure. Institutes represent the rules, mechanisms providing their accomplishment, and standards of behavior which structure the repeating interactions among citizens. It becomes obvious that the institutes determine and limit the set of alternatives which are available for each economic actor, they include all forms of the restrictions created by people to give a certain structure to human relations. However it is also important to understand that institutes, being standard restrictions, create opportunities which members of the society have, thanks to the fact that the same institutes reduce uncertainty, structuring activities of individuals. The set of the formal and informal institutes created in economy represents the institutional environment.
\end{abstract}

\section{Introduction}

Distinctions in the level of economic development, industrialization and innovation of economic system have predetermined several scientific-and-methodical approaches o the institutional transformations of the housing-and-municipal sphere. The allocated options differ in formation of various institutional structures with the definition of their staging in formation of the institutional environment and structure (Table 1).

Table 1. Development of institutional transformations in the housing-and-municipal sector from XX to the beginning the 21 st centuries.

\begin{tabular}{|c|c|c|c|}
\hline Period & Market subjects & $\begin{array}{c}\text { Owner's rights } \\
\text { system }\end{array}$ & $\begin{array}{c}\text { Administrative structure } \\
\text { of housing-and-communal } \\
\text { services }\end{array}$ \\
\hline $1917-1921$ & State & Rent & House committees and trusts \\
\hline
\end{tabular}

\footnotetext{
*Corresponding author: rn07@yandex.ru
} 


\begin{tabular}{|c|c|c|c|}
\hline $1921-1928$ & State and private sector & Property and rent & Condominium \\
\hline $1930-1937$ & State. Cooperation. & Rent & $\begin{array}{l}\text { Peoples's commissariat, } \\
\text { peoples 's managements }\end{array}$ \\
\hline $\begin{array}{l}1937-\text { the } \\
\text { middle } 50 .\end{array}$ & State & Property and rent & $\begin{array}{l}\text { House management, regional } \\
\text { housing management, } \\
\text { municipal housing governmen }\end{array}$ \\
\hline $\begin{array}{l}\text { From the } \\
\text { middles } 50-\mathrm{x} \\
\text { to the middle. } \\
\quad 80-\mathrm{x} \Gamma\end{array}$ & State & $\begin{array}{l}\text { Property, economic } \\
\text { maintaining, rent, } \\
\text { operational } \\
\text { management }\end{array}$ & $\begin{array}{c}\text { Committees of housing-and- } \\
\text { communal services, housing } \\
\text { trusts }\end{array}$ \\
\hline $1986-1991$ & $\begin{array}{c}\text { State and corporation } \\
\text { sector }\end{array}$ & Property and rent & $\begin{array}{c}\text { Ministry and local authorities, } \\
\text { state unitary enterprises, } \\
\text { cooperatives }\end{array}$ \\
\hline $1990-2004 \Gamma$. & $\begin{array}{l}\text { State, condominiums, } \\
\text { private managing } \\
\text { organizations, private } \\
\text { investors }\end{array}$ & $\begin{array}{l}\text { Property, rent, } \\
\text { concession }\end{array}$ & $\begin{array}{l}\text { Municipal, regional } \\
\text { authorities, state unitary } \\
\text { enterprises, housing-and- } \\
\text { communal complex, } \\
\text { condominium }\end{array}$ \\
\hline Since 2005 & $\begin{array}{c}\text { State (partially), business } \\
\text { environment, self- } \\
\text { governed associations of } \\
\text { owners of chambers }\end{array}$ & $\begin{array}{l}\text { Property, rent, } \\
\text { concessions, trust } \\
\text { management }\end{array}$ & $\begin{array}{c}\text { Региональные, } \\
\text { муниципальные Authorities, } \\
\text { business structures, } \\
\text { condominium, management } \\
\text { companies, self-regulatory } \\
\text { organizations }\end{array}$ \\
\hline
\end{tabular}

Thus, key value of the facility consists of the change of elements of institutional systems in infrastructure of housing and communal services which can be carried out by regulation from the state (is centralized) or in case of the active involvement from economic agents in regions and municipalities (is decentral).

\section{Methods}

At the moment the structure-forming document of process of reforming of housing-andcommunal services developed at the beginning of 2009 is getting more important [1]. The concept of the federal aim programme "The Comprehensive Program of Reforming and Modernization for 2010 - 2020." which has been accepted in February, 2010. Its realization is enabled at three levels:

- federal (study of legislative-and-methodological ensuring implementation of the program of credit financing taking into account requirements of bank community to potential borrowers);

- regional (coordination and control of realization);

- municipal (legislative fixing and implementation of drafts of the program).

This concept completely changes a funding mechanism for reforming and modernization of housing and communal services, in her the principles of attraction of the credit and mortgage capital in modernization of housing-and-municipal infrastructure are underlain [2]. 

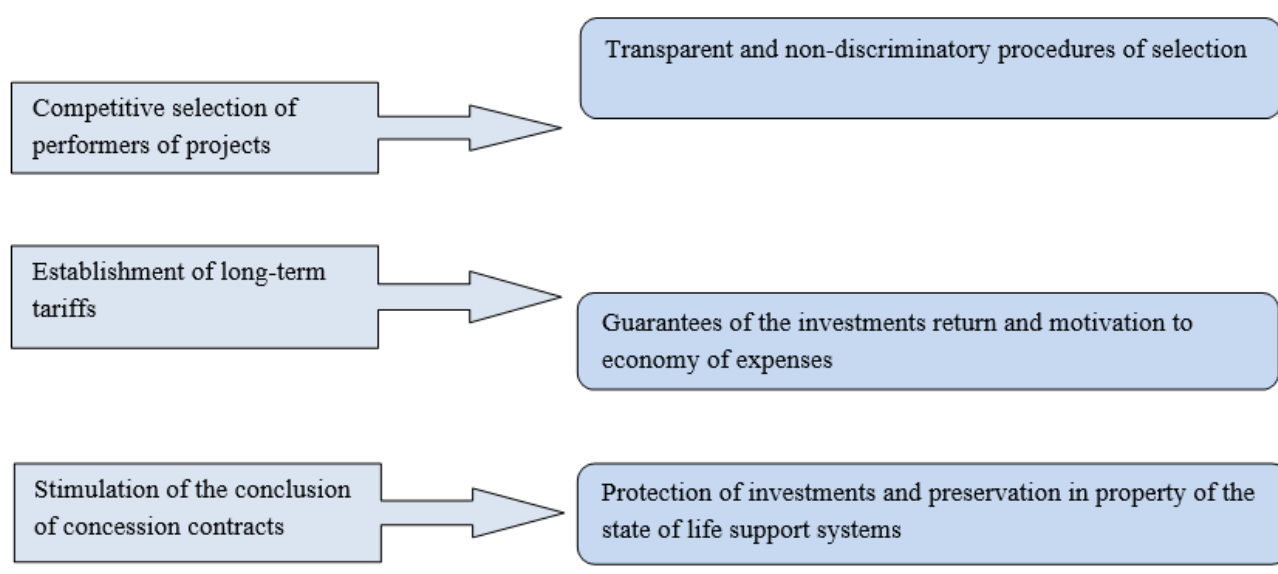

Protection of investments and preservation in property of the state of life support systems

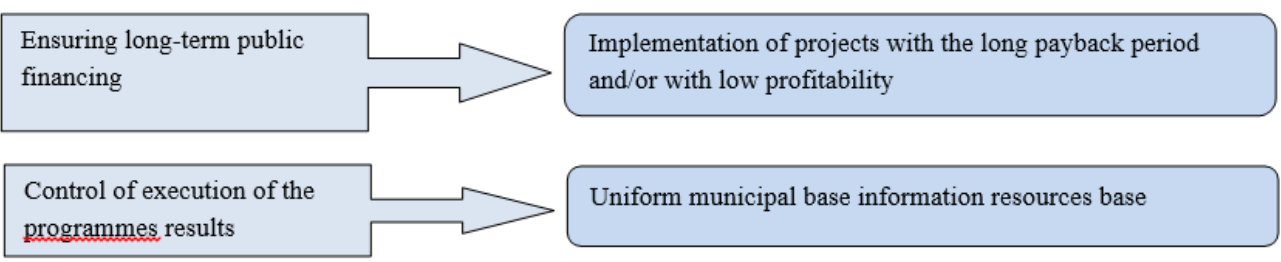

Fig. 1. Mechanisms of implementation of investment programmes of modernization of municipal infrastructure from 2010 to 2020 .

Capital-intensive projects with the long payback period partially have to be financed from budgetary funds of the Russian Federation, territorial subjects of the Russian Federation and municipalities (by compensation for expenses on payment of percent for the credit, granting the budgetary subsidies and issue of special long-term infrastructure bonds of territorial subjects of the Russian Federation, economic entities - initiators of investment projects). During the research of the process of reforming in work structural approach on the basis of which the bit-by-bit structure of functional and structural component mechanisms and actions of reforming of housing and communal services is allocated is applied $[3,4]$.

At such concept the model of effective management increases relevance the institutional housing-and-communal services transformations which have to reflect formation of modern mechanisms of management for the purpose of decrease in expenses (including financial) on granting housing-and-communal services. Thus, practical non-execution of transformations remains the main feature of institutional transformations in the housing market in Russia, i.e. there is no realization of changes of structure of housing actually [5]

\section{Results}

System transformation of housing-and-communal services includes institutional transformations from which new subjects of the market of housing services and housing stock result. Even at the beginning of economic reforms the most part of state ownership in the housing sphere (housing stock and facilities of the municipal infrastructure) have been transferred to a municipal property and, in a smaller part, to property of territorial subjects of the Russian Federation. Municipalization of housing-and-communal services of the took place during this period when this sphere in the increasing degree became subsidized as tariffs for housing and communal services haven't been mentioned in the course of a 
liberalization of the prices. And, at last, today, in the essence this transformation means transfer of assets (housing stock) from municipal maintaining in non-state and private. The economic basis as a fundament of these transformations as the institutional base and infrastructure of market reforms is the valuable, economical and legal and organizational basis for market transformations and reforms has to be for this purpose most well prepared.

In municipal infrastructure along with business of the Russian national scale (Russian Communal Systems, etc.) the regional private companies participating in competitions on management of municipal property began to be created. The analysis of stages of formation of the market in housing sector, processes of privatization and incorporating state ownership has shown that the existing control system of the enterprises doesn't correspond to opportunities of new owners for management and control of their activity, criteria of need of their functioning aren't fulfilled, lack of strategy in management of the property complex of the enterprise leads to irrational expenses and short-reception of the income in budgets of all levels, inefficient financial management and low skill level of personnel, etc. exist.

Noticeable influence in advance of the transformations in housing sector and their adaptation to concrete and appreciably to the differing conditions of regions and municipalities was occupied by public organizations - the associations, consumers unions of services, producers of services created not only by the branch, but also territorial principle. Introduction of institute of self-regulation to housing-and-communal services, according to the Act of the Russian Federation "About self-regulatory organizations", is determined by the need of formation of effective communication for the "power-businessthe consumer" system; carrying out the deep cardinal transformations promoting emergence of a large number of managing organizations, resource supplying and marketing enterprises ready to offer the potential for the solution of branch tasks at the federal, regional and municipal levels; the administrative self-determination of market structures expressed in readiness of participation in regulation as own technological processes in the form of development of production schedules and standards, and activity in the market of these services in the form of uniform rules of activity in the market and creations of mechanisms of additional responsibility on implementation of obligations to consumers of services. Transition to self-regulation is directed to increase in efficiency of mechanisms of integration of state regulation and the market self-regulating principles of activity of subjects.

Housing-and-communal services are obliged to provide the population with the vital services and necessary engineering infrastructure. The annual turnover in the sphere of housing-and-communal services exceeds 4.1 trillion rubles, these are more than 5.7 percent of gross domestic product of Russia [3]. According to Federal State Statistics Service, the volume of housing stock in the Russian Federation makes 3.3 billion sq.m, including apartment houses - 2.4 billion sq.m (that makes 72 percent of total amount of housing stock) [3]. According to survey conducted in May, 2015, most of citizens (55 percent) considers unfair the sum which they pay for utilities, 63 percent of the respondents have set the price of utilities overestimated, at the same time more others residents of towns with the population from 50 to 100 thousand people ( 75 percent) suffer high cost of housing-andcommunal services [3]. At the same time 83 percent of respondents are positive to installation of metering devices. For the decrease in the general payment for the consumed municipal resources the vast majority of respondents (71 percent) have already installed metering devices of water consumption [6,7].

\section{Discussion}

According to the Federal Service for the Oversight of Consumer Protection and Welfare, 
only 62.1 percent of the population in Russia consume qualitative water. In the sphere of water supply to standard level only 55.5 percent of the water pumped in network are purified, and in the sphere of water disposal and sewage treatment to standard level only 45 percent of sewage are purified. 48 percent of the population has interruptions in supply of hot water, cold water - 42 percent of the population interruptions in supply of cold water, 28 percent of the population have problems with the electric power.

At the same time, according to the researches conducted in May, 2015, already more than a half of respondents began to estimate well quality of utilities, and 12 percent of respondents have noted improvement of their quality, mainly it is residents of the small cities ( 20 percent) and villages (15 percent).

According to survey conducted by the All-Russian Public Opinion Research Center in 2015 , the greatest dissatisfaction of citizens is connected with insanitation of ladders and irregular cleaning of an entrance (38 percent), the bad condition of roofs, walls and ceilings (36 percent) which have rotted through and faulty water and sewer pipes (33 percent), insanitation of cellars (27 percent), malfunction of doors, window frames, balconies (24 percent), frequent breakages of elevators (11 percent) [8].

According to the expert estimates, annual investment requirements of municipal sector make not less than 500 billion rubles (more than 200 billion rubles are the investments into the sphere of heat supply, more than 100 billion rubles are the investments into the sphere of water supply, more than 100 billion rubles are the investments into the sphere of water disposal). At the same time the sphere of housing-and-communal services has the huge potential of increase in efficiency which, by expert estimates, reaches 40 percent, but it is possible to use it only on condition of inflow of investments and the use of the most effective technologies.

Throughout the reforms, the Government of the Russian Federation has published the Order dated 1/26/2016 by N 80-p "The strategy of development of housing-and-communal services in the Russian Federation for the period till 2020". Formation of active and responsible owners of chambers in the apartment houses is distinguished from the key directions of realization of Strategy (further - $\mathrm{AH}$ ).

Particularly, Strategy is aimed at the business development, strengthening of the competitive environment and attraction of private investments into the sphere of housingand-communal services, improvement of system of the relations between owners by $\mathrm{AH}$, managing organizations and resource supplying organizations, and also in general increase in power efficiency of branch. In Strategy it is specified that the main objective of public authorities in housing sector is creation of the system of standard and legal regulation providing effective functioning and sustainable development of housing-and-communal services, providing including reduction the administraktivnykh of procedures, prevention of corruption. Point 2 of the Order of the Government of January 26, $2016 \mathrm{~N} \mathrm{80-p}$ is recommended to public authorities of subjects of the Russian Federation and local governments, to be guided by provisions of Strategy, when developing regional target programs and other documents, including legal acts, in the sphere of housing and communal services. Housing-and-communal services development priorities, according to Strategy, are granting qualitative housing and communal services to consumers for providing to citizens of comfortable conditions of accommodation and existence of balance of interests of various participants of the sphere of housing and communal services. Resource ensuring realization of Strategy is carried out at the expense of the budgetary and non-budgetary sources formed in the order established by the legislation of the Russian Federation $[9,10]$. Realization of Strategy is planned in 2016 - 2020.

According to the results of monitoring of realization of Strategy it is planned to prepare annual reports for the Government of the Russian Federation, and also to consider the specified results at meetings of the interdepartmental working group on questions of 
housing-and-communal services created by the decision of the Russian Prime Minister Medvedev D. A. of May 20, 2015 N 3083p-P9.

Particularly, "Realization of Strategy will allow to increase comfort of conditions of accommodation, will promote modernization of objects of housing-and-communal services, transition to the principle of the use of the most effective technologies, ensuring availability of apartment houses to disabled people and other handicapped groups of the population".

Decrease in costs of production of housing-and-communal services often does not influence the cost of payment of housing-and-communal services by the population. It is connected with dishonesty of management companies.

Besides, in Strategy, as well as in the existing standard and legal base there are no investment, innovative, modernization, tax mechanisms capable to make housing-andcommunal services the attractive strategic direction of development capable effectively to work, exercising constitutional right of each citizen on worthy housing through realization of state mechanisms at each level of management as guarantor of constitutional rights and freedoms. It should be noted that the legislator hasn't provided supervision at implementation of provisions of Strategy. According to D. P. Gordeev conducting the legal adviser of the direction "Municipal economy" of Institute of City Economy Fund: "The question is in as far as efficiency equally is understood by the power, business and consumers how adequate will be regulation. To reduce administrative procedures it is necessary at first to stop them to produce. And it is a trend of the last years. He is shown also in introduction of model of the regional operator of overhaul, and in introduction of GIS housing-and-communal services and other systems of the reporting, in licensing. The Korruptsiogennost of procedures of licensing and state housing supervision follows from unreasonably high penalties, a possibility of a side play of the inspectors accepted by results of corrective actions to persons under surveillance to the organizations and persons" [11].

Besides, according to Aligadzhiyeva M. I. and Mamayeva U. Z., with which it is impossible won't agree: "Stage-by-stage solutions of reforming come down to formation of the structures capable to accumulate the maximum volume of functions within one organization. At the same time the problem of increase in controllability of branch due to integration of structural elements in branch is solved, but the purpose, which is the improvement of quality of housing-and-communal services in combination with optimization of expenses as the created enterprises had no orientation to the consumer and any interest in decrease in the expenses" suffers.

It is also necessary to note that "the commercial, but not unitary enterprises are the most adapted for the market relations, as we know. One of solutions of the problems connected with management in housing-and-communal complex is the arrival of the private companies ready to carry out effective operation of engineering networks and constructions. Being applicants a number of requirements which satisfaction is impossible without introduction of effective management at the transferred enterprise" $[12,13]$ has been shown to the private companies.

Membership of management companies in self-regulatory organizations, their accountability, openness of information on results of realization of Strategy has to increase the personal and social responsibility of this participant of the market of housing-andcommunal services $[14,15]$.

\section{Conclusions}

The establishment of management companies for needs of housing-and-communal services or housing-and-communal complex, the establishment of public-private partnerships for needs of housing and communal services or ZhKK, their licensing or membership in self- 
regulatory organizations, depending on a kind of activity, annual certification of employees on compliance to qualification requirements for the post in housing-and-communal services, compliance to the professional standard and other requirements for branch, adoption of effective administrative decisions, introduction of concessions, participation in tenders, openness of information, the accountability, the submission to control - on the one hand; creation for housing and communal services of attractive investment, innovative, modernization, tax model for implementation of the priority investment project in compliance of the Federal Law "About Investment Activity in the Russian Federation Which Is Carried Out in the form of Capital Investments", modification and additions at the federal, regional and municipal levels of management in the existing legislative base, regarding concerning, on the other hand; tariff setting improvement, from the third party is and there is the structure of reforming of housing and communal services in the crisis situation existing for centuries in housing-and-communal services of Russia. It is very important not to go to repartition and/or capture of property of housing and communal services, housing-and-communal complex as concepts of inseparable improvements, the property rights to them and legal consequences generating them on standards of the Civil Code of the Russian Federation nobody cancelled. Besides, to start a solution, it is necessary to bring the directions of reforming of housing and communal services in the list of the priority directions of development of economy of the Russian Federation. The efficiency of the carried-out actions for reforming of housing-and-communal services at the federal, regional and municipal levels of management is fundamental base when forming relationship: the state - the citizen, regarding realization of the guarantees, the rights and freedoms enshrined in the basic law - Constitutions of the Russian Federation.

\section{References}

1. N.G. Verstina, N.N. Taskaeva, T.N. Kissel, E.M. Akimova, A.V. Fedosina, International Journal of Applied Engineering Research 10 (20), 41156 - 41163 (2015)

2. E.Yu. Chibisova, Journal of economy and entrepreneurship 5-2 (58-2), 600-603 (2015)

3. E.Yu. Chibisova, Assessment of financial efficiency of the investment project (Marketing, Moscow, 2004)

4. A. Mottaeva, MATEC Web of Conferences 73, 07020 (2016)

5. E. Stein, N. Taskaeva, E. Chibisova, Procedia Engineering 165, 1410-1416 (2016)

6. E.M. Akimova, E.M. Stein E.M., Y.S. Prokhorova, Journal of Advanced Research in Law and Economics 6(3), 472-487 (2015)

7. O.B. Skripnik, S.A. Lochan, D.S. Petrosyan, Challenges of modern Russia: the rational use of managerial potential of national and regional economy (KNORUS, Moscow, 2006)

8. O.B. Skrypnik, Reforming of institutional system and environment of the market of housing-and-communal services (Finances and statistics, Moscow, 2007)

9. O.B. Skrypnik, D.S. Petrosyan, Auditing and financial analyses 6, 363-368 (2016)

10. E.Y. Chibisova, Journal of International Scientific Publications: Economy \& Business 5(2), 600 (2015)

11. V.V. Buzyrev, V.S. Chekalin, Economy of the housing sphere (INFRA-M, Moscow, 2016)

12. V.S. Morozov, N.N. Taskaeva, Man in India 7 (96), 2009-2023 (2016)

13. M. Jocovic, B. Melovic, N. Vatin, V. Murgul, Applied Mechanics and Materials, 678, 644-647 (2014) 
14. I.S. Polyakova, E.Yu. Chibisova, Journal of economy and entrepreneurship 5 (70), 579-582 (2016)

15. S.Kanyukova, N.Vatin, D.Leybman, T.Sazonova, Procedia Engineering, 165, 19181924, (2016),DOI 10.1016/j.proeng.2016.11.942

16. I. Polyakova, E. Vasilyeva, Procedia Engineering 165, 1410-1416 (2016)

17. N.G. Verstina, E.M. Akimova, T.N. Kisel, E.Y. Chibisova, V.A. Lukinov, International Journal of Economics and Financial Issues 5 (3S), 217-223, (2015) 